International Journal of Emerging Markets, http://doi.org/10.1108/IJOEM-04-2021-0555

\title{
What effect did Green Credit have on China's energy or emission intensive firms?
}

\begin{abstract}
The role of energy or emission intensive firms face contradictory demands from advancing economic development and environmental improvement and protection and thus require appropriate policy interventions to balance the two needs. China's "Green Credit" policy that restricts loans to energy or emission intensive firms provides an example to study the impact of these kinds of policy intervention. Using the data of all A-share listed companies in Shanghai and Shenzhen stock exchanges, our paper empirically analyzes the impact of Green Credit on performance of these energy or emission intensive firms. The conclusions are as follows: (1) the Green Credit Guidelines issued in 2012 have played a restrictive role in effectively preventing the risks that could be encountered in the implementation of Green Credit to energy or emission intensive firms; (2) using DID and PSM-DID method and the dynamic effect method, we found that from 2012 to 2015, Green Credit had an inhibiting effect on the performance of energy or emission intensive firms. This inhibiting effect was weakenedin 2016, and turned into a positive promoting effect in 2017; (3) the fiirms' performance change around 2015 showed that Green Credit promoted their green transformation and upgrading; and (4) loans were helpful to the performance of energy or emission intensive firms to some extent, but government subsidies were not significant. The results suggest that the government, banks and other institutions should
\end{abstract}


dynamically assess the implementation results of Green Credit on energy or emission intensive firms.

Keywords: energy or emission intensive firms; Green Credit; firm performance

\section{Introduction}

In recent years, with the development of society and economy, severe climate change, energy consumption and depletion, serious pollution emissions and other problems have appeared worldwide, and the natural environment around the world has been deteriorating (Yanli Wang et al., 2020). Therefore, the urgent problem for all countries is how to find effective and sustainable development solutions to balance economic benefits and environmental protection (Nabeeh et al., 2021; Y. Zhang et al., 2020). To bring the current financial system into line with the 2030 Agenda for Sustainable Development, the United Nations Environment Programme has been working with financial authorities and financial regulators around the world to channel funds to green projects and ultimately to achieve the Sustainable Development Goals (Lee, 2020). Among them, the Equator Principle ${ }^{1}$ is one of the most famous green guiding principles for banks, which mainly

\footnotetext{
${ }^{1}$ The Equator Principle is "a risk management framework adopted by financial institutions to identify, assess and manage environmental and social risks in projects". At present, it has been adopted by 111 financial institutions in 37 countries.
} 
identifies, assesses and manages environmental and social risks that commercial banks face when making project financing decisions (S. Xu, 2020).

Green Credit is an international practice based on the equator principles, and has been supported and valued by more and more financial institutions and spread around the world (Scholtens \& Dam, 2007; Contreras et al., 2019; Chen et al., 2018). Under the guidance of Green Credit, banks and other financial institutions provide credit funds with the favorable interest rate to energy-saving and environment-friendly firms, while implement credit restriction and high interest rate loan policy to firms that pollute the environment, so as to achieve the "green allocation" of funds (J. Y. Liu et al., 2015; Junli, 2013; J. Y. Liu et al., 2015; B. Zhang et al., 2011).

Green Credit Guidelines in 2012 provided a good exogenous shock condition for the research of Green Credit in this paper. Green Credit started late in China. It was first proposed in the Opinions on Implementing Environmental Protection Policies and Regulations to Prevent Credit Risks jointly issued by the former State Environmental Protection Bureau, The People's Bank of China and the former China Banking Regulatory Commission in 2007. And then, the Chinese government has promulgated a series of Green Credit policies one after another (Guo et al., 2019). The Green Credit Guidelines in 2012 was the most crucial and landmark one. Before 2012, the green credit policies were mainly to guide banks to build awareness of environmental protection and sustainable development; after 2012, the policies have shifted to the improvement and perfection of the evaluation system for the implementation of green credit policies (Ling et al., 2020). At the same time, 2012 is also a recognized node in the current academic research (Y. 
Hao \& Yan, 2020; Wen et al., 2021), so we choose 2012 as the implementation year of the Green Credit policy.

Under the support of government policies, it has formed a strong and coordinated development trend of green finance in China. By 2017, the Green Credit balance of 21 banking institutions in China had reached 7.5 trillion yuan. Meanwhile, the fund supply of Green Credit was still a drop in the ocean compared with the fund demand of green investment in the real economy (Wang Kangshi, Sun Xuran, 2019). On the other hand, Green Credit has encouraged banks to reduce financing for energy or emission intensive industries (Harper Ho, 2018). In 2013, the CBRC issued the "Key Points for Supervision of Banks in 2013", requiring banks to strictly supervise to nine industries, including real estate, construction machinery, steel, non-ferrous metals, cement, coal chemical industry, shipbuilding, wind power equipment and photovoltaic. Loans to industries with high energy consumption, high pollution and overcapacity fell by 24.8 percent in 2013, according to the 2013 Social Responsibility Report on China's banking sector released by the China Banking Association. Given the large size of sectors being impacted, studying the impact of Green Credit on the loans and performance of energy or emission intensive firms is within the growing literature on green finance.

The previous literatures almost gave a one-size-fits-all assessment of Green Credit to energy or emission intensive firms, and basically all considered that Green Credit constrained the credit financing of these firms. But they haven't been studied from a dynamic point of view. There were few studies on the effect of Green Credit implementation on the performance of energy or emission intensive firms. Because the fundamental purpose of Green Credit was to improve and upgrade energy or emission intensive firms to green firms, rather than blindly restrict their credit. 
Therefore, when the production of energy or emission intensive firms met the environmental requirements, banks may dynamically adjust their lending strategies and re-lend to these firms. From a dynamic perspective, this paper studied the impact of Green Credit on the performance of energy or emission intensive firms, because the performance can better show the development status of firms.

In this paper, the data of Chinese listed firms from 2007 to 2019 were used to empirically test the impact of Green Credit on the performance of energy or emission intensive firms by adopting DID and DID-PSM method and the dynamic effect method, which previous literatures had not examined. With the change of time, we analyzed whether this effect was inhibiting or promoting, whether change occurred, and whether the short-term and long-term effects were different. The results showed that from 2012 to 2015, Green Credit had an inhibiting effect on the performance of energy or emission intensive firms. This inhibiting effect was gradually weakened in 2016, and it turned into a positive promoting effect in 2017. The results suggest that the Green Credit should gradually weaken the capital constraint of energy or emission intensive firms and encourage them to carry out technological innovation. The government should set up a better system of penalties and incentives to promote more green investment. The government, banks and other institutions should dynamically assess the implementation results of green credit policies on energy or emission intensive firms.

The main contributions of this paper are as follows: (1) This paper expands relevant studies on the Green Credit policy. The existing literature mainly focuses on the study of Green Credit from the macro level and the static perspective of firms. However, from the micro perspective of the dynamic change of energy or emission intensive firms' performance are relatively lack of 
research. (2) through the DID and DID-PSM model, this paper provides reliable empirical evidence of how the performance of these firms are affected by Green Credit; (3) through dynamic evaluation of the implementation effect of Green Credit, this paper discusses the perfomrnace changes of the energy or emission intensive industries.

The structure of this paper is as follows: Section 2 reviews the literature, Section 3 builds the empirical models, and Section 4 discusses the findings and the last section concludes the paper with some recommendations.

\section{Literature review}

With the increasing demand and action of the global response to climate change, Green Credit has recently attracted extensive attention from scholars. Zhang et al. (2019) summarized the current situation and development trend of green finance by means of bibliometric analysis. Green Credit comes into being in the process of government's implementing credit policies and is developed by banks and firms in actual implementation. This part reviews the existing literature on Green Credit from the perspective of government, banks, and firms .

\subsection{The role of government in Green Credit}

The essence of Green Credit was a mandatory reform implemented by the government in China, a country in the primary stage of green finance (Ling et al., 2020). So far, the government, through the People's Bank of China, the Committee of Banking Supervisors and other traditional channels, has imposed rules that banks must follow, such as Green Credit (Sun et al., 2019). 
Scholars differ in their assessment of the actual role of the government in Green Credit.

Some scholars consider that government subsidies (general government subsidies, not specifically referred to as environmental subsidies) can not only promote product innovation, but also reduce environmental pollution, so that firm innovation and environmental benefits achieve a win-win situation, that is, government subsidies have environmental protection effect (J. Liu et al., 2020; Yang Wang \& Zhang, 2020; R. Zhang et al., 2020). However, Yu \& Chi (2010) thought that if the government adopted credit policies to support low-pollution production technologies and combined financing with environmental problems to improve environmental pollution, such green credit policies may cause uncertainty of economic growth and even damage the economic growth rate.

To sum up, the government is playing a leading role in Green Credit. The direct action of the government is mainly in the aspect of government subsidies. How government subsidies affect the performance of energy or emission intensive firms is rarely studied in previous literature.

\subsection{The role of banks in Green Credit}

In the context of widespread inadequate regulation at both international and national levels, banks invest in industries that cause environmental pollution and climate change, which makes banks' lending activities linked to commercial activities that damage the natural environment (Stephens \& Skinner, 2013). Sadorsky (2010) found that financial developments have led to increased carbon emissions by increasing the demand for energy. Using a standard macroeconomic model to analyze the effectiveness of fiscal policy in addressing climate change, Catalano et al. (2020) suggested that the late remedial action on climate-related events was far less 
than early preventive action. Many scholars believed that Green Credit was a kind of sustainable financing. By developing Green Credit business, banks can lend to different firms considering their environmental level, which helped society achieve sustainable development goals (Nandy \& Lodh, 2012). Taking Chinese listed firms from 2012 to 2019 as samples, Xing et al. ( 2020) discussed whether banks attached importance to green management of firms after the release of Green Credit in China. It turned out that firms with better green management got more bank credit.

Banks played a key role as enforcers in Green Credit. When banks executed Green Credit concretely, what attribute of the energy or emission intensive firm would be helpful for the firm to obtain loan? It has not been studied in previous literature.

\subsection{The impact of Green Credit on energy or emission intensive firms}

The financing cost and borrowing capacity of firms reflect the impact of Green Credit on the firms, indicating the support strength and preference of this policy (He, Wu, et al., 2019). Some scholars thought that the reason for the financing constraint of polluting firms was that the external financing environment of energy or emission intensive firms in China had changed greatly (Y. Hao et al., 2019; X. Xu \& Li, 2020; J. Xu \& Nickel, 2017;Wen et al., 2021). The government had increasingly emphasized "green GDP" and promulgated regulations to reduce environmental pollution, which severely constrained the financing of these firms and seriously affected their sources of capital (Y. Hao et al., 2019; Song et al., 2021). G. Hu et al. ( 2021) suggested that the Green Credit can stimulate green innovation of energy or emission intensive firms through credit constraints to realize green transformation. 
The main goal of Green Credit is to improve the ecological environment by promoting the technological innovation of energy or emission intensive firms and reducing their pollution emission. However, as technological innovation is a huge, high-risk and long-term investment, previous literatures have given different conclusions as to whether energy or emission intensive firms would invest to promote technological innovation under the influence of Green Credit. F. Hao et al. (2020) estimated the DID model using samples from The CSMAR Database (20072018) and China Provincial Marketization Index Report (2018). The results showed that the implementation of Green Credit promoted technological innovation of polluters. J. Y. Liu et al. (2015) considered that in the long run, the Green Credit would restrain the investment of polluting firms and had poor effect on the upgrading and transformation of the industrial structure. As a result of the impact of reduced investment and financial constraints, the profitability of highly polluting firms declined, reducing their competitive advantage in the market, leading to a large number of these firms to withdraw from the market (Dongyang Zhang, Du, \& Chen, 2019).

Some scholars used DID model to study the effect of Green Credit on the financing constraints caused by energy or emission intensive firms (Yanli Wang et al., 2020; X. Liu et al., 2019; F. Hao et al., 2020). Therefore, DID model was also adopted in our paper to make the results more comparable.

Energy or emission intensive firms were the actual recipients of Green Credit. How did the implementation of Green Credit affect the loans and performance of energy or emission intensive firms? This paper will empirically study this topic. 


\section{Empirical evidence}

\subsection{Data}

Since the new accounting standards came into effect in 2007, we have collected data on all A-share firms listed on the Shenzhen and Shanghai exchanges between 2007 and 2019 from WIND. Among the nine industries in which the CBRC aims to strictly supervise in 2013, seven were energy or emission intensive firms. Because the profit model is quite different from other industries, the real estate industry was deleted. In the end, this paper selected 133 firms from energy or emission intensive firms, including industries of Shipbuilding, Nonferrous metal, Construction Machinery, Cement, Coal Chemical, Iron and Steel, as the treated group. As for the control group, because the firms in green industries such as "Photovoltaic" and "Wind energy" are supported by green financial policy, their received loans and profits are different from energy or emission intensive firms and general ones, so these firms were deleted from the sample. Finally, we got 810 firms as the control group which covered all industries except energy or emission intensive ones and green ones. Thus, the control group was not affected positively or negatively by the Green Credit policy, which ensured the rationality of the application of DID model.

The variable names and definitions adopted in this paper are shown in Table 1. ROA and ROE are commonly used indicators to measure the profitability of a firm, ROA measures the profitability of the firm's total assets, while ROE profitability of Shareholders' own capital. In this paper, the Green Credit policy will affect the firms' loans, which are more closely related to the total assets of the firm compared with shareholder capital. In addition, the fluctuation range of ROE is particularly large, for example, it was from -8257 to 1676 in this paper, while that of ROA 
was small (from -1.65 to 2.50 in this paper). The different methods of outlier deletion will have a significant impact on the empirical results. For the two reasons, this paper chose ROA as the variable to reflect the impact of Green Credit on the firm performance.

We use the growth rate of the loans $\left(\operatorname{Loan}_{t}-\operatorname{Loan}_{t-1}\right)$ to reflect changes in lending. Because it is more reflective of the long-term and sustainable impact of lending on the performance of the firm. Therefore, 2007 is the beginning year of the original data collection, and 2008 is the beginning year of the DID model.

In addition, in the new accounting standards, government subsidies of listed firms are included in the non-operating income of the annual reports. Because there are large differences in the types of subsidies among firms, and the different forms of subsidies were not classified until 2009, we use the sum of all subsidies without categorizing these forms, the same as Zhang et al., (2014). It should be noted that the government subsidies generally include the return of tax incentives, Value Added Tax (VAT) return and financial subsidies (Xiong \& Yang, 2016). In particular, the details of government subsidies for energy or emission intensive firms could involve environmental protection fund subsidies, financial subsidies for technical renovation projects, sewage treatment and water-saving renovation projects, etc. These subsidies, collectively known as environmental subsidies, fall into two main categories - subsidies for emission reduction equipment and subsidies for pollution reduction. Therefore, subsidies are given to these firms to promote their transformation and upgrading. We added the square terms of loans and subsidies in the model to test whether these two variables had a non-linear effect on firm performance. Restrictions on their loans are meant to force them to change their environmental conditions, as 
well as to encourage them to make the transition to green. So, limiting loans and subsidizing them both have the same goal, just two different means, not contradictory.

Other financial indicators such as cash flows from operating activities, Capital expenditure, Ratio of assets to liabilities and the size of firm can reflect the firm's profitability, solvency, growth and operating ability.

\section{Table1. Variable Definitions}

Table 2 shows the descriptive statistics of the firms in the control group and in the six treated industries. It can be seen that the proportion of state-owned firms and average firm size in the control group were lower than those in the treated group, which was consistent with the fact that there are more large-scale state-owned firms in these industries of Shipbuilding, Nonferrous metal, Construction Machinery, Cement, Coal Chemical, Iron and Steel. In addition, the average ratio of loan growth to total assets in the control group was lower than that in the treated group, while the average ROA was higher than that in the treated group during the whole period, which indicated that the loan efficiency of energy or emission intensive firms was lower than those in other industries.

Table 2. Summary Statistics of Variables 


\subsection{The potential impact of Green Credit: DID and PSM-DID estimations}

The Difference-in-Difference (DID) model is a policy evaluation model adopted in recent literature, which can alleviate endogeneity problems caused by omission variables, reverse causality, measurement bias and other factors (Ashenfelter \& Card, 2006; Gruber \& Poterba, 2006; Lechner, 2010). During the implementation period of Green Credit, this policy for energy or emission intensive firms can be seen as a quasi-natural experiment. So, we used DID to analyze the impact of this policy on the performance of energy or emission intensive firms. The sample was divided into two groups. During the implementation period of Green Credit, energy or emission intensive firms were included in the treated group. During the non-implementation period of Green Credit, they were included in the control group and this group also included other firms (the green firms were removed from the other firms) that were never subject to Green Credit. In order to make the results more robust, this paper further adopted PSM-DID (Heckman, J. J., Ichimura, H., \& Todd, 1997). Firms with characteristics as similar as possible to the treated group that were not affected by Green Credit were selected as the control group to eliminate sample bias. If the result of PSM-DID was similar to that of DID, it can be indicated that the result was robust.

According to the previous analysis, the implementation period of Green Credit was from 2012. Accordingly, the sample period included two sub-periods. The first period was 2008 2011. In order to investigate the lasting change of the impact of Green Credit on the performance of energy or emission intensive firms, the values of "2012 2019", "2012 2015" and "2016 2019" were respectively adopted for the second period. In the first period, neither the treated group nor 
the control group was subject to policy restriction, while in the second period, the treated group was subject to policy restriction while the control group was not.

The DID model was as below:

$$
\begin{aligned}
\mathrm{ROA}_{i, t}= & \beta_{0}+\beta_{1} \text { Treated }_{i, t}+\beta_{2} \text { Time }_{i, t}+\beta_{3}\left(\text { Treated }_{i, t} \times \text { Time }_{i, t}\right)+ \\
& \sum_{k=1}^{K} \beta_{k+3} X_{k, i, t}+\mu_{i+} v_{t}+\varepsilon_{i, t}
\end{aligned}
$$

where, $\mathrm{ROA}_{i, t}$ is the Return on Assets measure for firm $i$ at time $t$;

$\beta_{0}$ is the intercept term of the fixed-effects regression;

Treated $_{i, t}$ is a dummy variable and is 1 if firm $i$ is in the treated group and 0 denotes one firm in the control group;

Time $_{i, t}$ is a dummy variable and is 1 in the period of "2012 2019", "2012 2015", "2016 2019" but otherwise it is 0 ;

$\beta_{1}, \beta_{2}$ are the coefficients of Treated $_{i, t}$ and Time $_{i, t}$ respectively. $\beta_{3}$ is the coefficient of (Treated $_{i, t} \times$ Time $\left._{i, t}\right)$ and is referred to as the DID estimator;

$X_{k, i, t}$ is the $k$ th control variable for firm $i$ at time $t$;

$\beta_{k+3}$ is the coefficient of the $k$ th control variable in the regression.

$\mu_{i}, v_{t}$, and $\varepsilon_{i, t}$ indicate the fixed effect of firm, the fixed effect of year and the error respectively. 
The DID estimator $\beta_{3}$ in (1) will determine whether the performance of firms in the treated group during the period of Green Credit was affected by the restriction relative to other firms after the various control variables were taken into account.

Figure 1 presented the average ROA of the treated and control groups from 2007 to 2019.

From Figure 1, we found that the trends in the average ROA in the treated and control groups were similar and that the turning points were 2010 and 2015. However, the gap between the treated and control groups began to widen from 2012 (the beginning of Green Credit implementation).

In 2012, the ROA of energy or emission intensive firms began to open a gap with the control group. In 2015, the overall average ROA of energy or emission intensive firms was negative, and then began to rebound sharply after 2015. The decline of ROA reflected the direct negative impact of Green Credit on the performance of firms. During the implementation period of Green Credit, the ROA of energy or emission intensive firms decreased significantly compared with the control group.

Figure. 1. Average ROA of Treated Group and Control Group in 2007-2019

We further conducted a parallel trend test with a regression model. Firstly, the year 2012 that the policy of Green Credit began to be implemented as taken 0, the years of 2007-2011 were taken as $d-5, d-4, d-3, d-2$ and $d-1$, and the years of 2013-2019 were taken as $d+1, \cdots \cdots, d+7$. Then the variables of $d-5, \cdots \cdots, d+7$ were be assigned values. For example, $d-5$ was taken as 1 if a company 
was in the treated group and in the year 2007, otherwise, d-5 was taken as 0 . finally, a fixed-effect model was conducted with the variables $d-5, \cdots \cdots, d+7$ and other control variables were included in the model. The results show that the coefficients of $d-4, d-3, d-2$ and, $d-1$ were not statistically significant, which indicated that that the parallel trend hypothesis was supported, the result was shown as figure. 2 . In addition, we found that the coefficients of $d+1, d+2$ and $d+4$ were not statistically significant while those of $d+3, d+5, d+6$ and $d+7$ were statistically significant, which showed that the Green Credit policy actually had a negative impact on the efficiency of energy or emission intensive firms in the early stage of implementation.

Figure. 2. The result of parallel trend test

Table 3 showed the difference in the average ROA between the energy or emission intensive firms and control groups during the period of policy implementation and non-implementation. The samples included all firms and the matched firms with the PSM method. In the process of PSM processing, there were 11316 observations in years of 2018-2019, of which 54 and 1 observations in the treated group and the control group were not in the common range, and the remaining 11261 observations were in the common range. Figure. 3. described the common range of propensity scores.

Figure. 3. The common range of propensity score 
It can be seen that although there were decreases in the average ROA for both groups during the policy period due to the impact of a business cycle, there was a sharper decline for the energy or emission intensive firms in the policy period than for the control group. From the results shown in Table 3, we can see that there was a decline in average ROA by 0.024 for the energy or emission intensive firms in 2012-2015, but only a 0.007 decline in the average ROA for all firms in the control group in the same period. The differences were statistically significant at the level of $1 \%$. Moreover, the results were consistent when the control group was determined by the PSM approach. From Figure 1 and Table 3, it can be further assumed that Green Credit had a negative impact on the performance of a firm in 2012-2015.

Table 3. Difference in the Average ROA of the Different Groups

Then we conducted the DID model and PSM-DID model. Considering that government subsidies recorded in non-operating income may also promote firm performance, in order to avoid possible endogenous problems, we used the lagging variable as an instrumental variable to test the endogeneity of subsidies and their squared terms. The results showed that the endogeneity problem existed between subsidies and firm performance. Then the tests of the underidentification and weak identification were carried out for these two instrumental variables. It showed that there was no such problem with instrumental variables. Therefore, the lagged subsidies and lagged square item of the subsidies were added into the DID model analysis. 
Table 4 The DID Result of energy or emission intensive firms (Dependent variable: ROA)

Table 5 The PSM-DID Result of energy or emission intensive firms (Dependent variable: ROA)

Table 4 and Table 5 showed the DID and PSM-DID Result of energy or emission intensive firms. In Table 4, the coefficients of Treated $\times$ Time were significantly negative in 2012-2015, significantly positive in 2016-2019, and negative but not significantly in 2012-2019. Meanwhile, it should be noted that the coefficient in 2012-2019 was smaller than that in 2012-2015, which may be due to the different effects of Green Credit in different periods. The results of PSM-DID were shown in Table 5 . The coefficients of Treated $\times$ Time were significantly negative in 20122015, positive but not significantly in 2016-2019, and negative but not significantly in 2012-2019. The coefficient in 2012-2019 was also smaller than that in 2012-2015. It can be seen that DID and PSM-DID had similar results. The coefficient in 2012-2015 was negative, which indicated that Green Credit had an inhibiting effect on the performance of energy or emission intensive firms. In 2016-2019, Green Credit may have a positive effect on the performance of energy or emission intensive firms, but it was not obvious. Therefore, we drew preliminary conclusions: The impact of Green Credit on energy or emission intensive firms were different in the short term and the long term; The Green Credit inhibited the performance of energy or emission intensive firms at the initial stage, but in the long run, this inhibiting effect weakened and may gradually turn into a 
positive promoting effect. In the next section, we further conducted dynamic effect analysis to verify the robustness of the results.

As for the control variables, the growth in the ratio of loans to total assets had a significantly positive effect to the performance of firms in both DID and PSM-DID model. This result showed that loans could improve the performance of firms. As for the variable of subsidies, the coefficients of subsidies were different and both not significant. The subsidy coefficients are not significant, indicating that subsidies play a small role in upgrading and transformation.

Government subsidies for the energy or emission intensive firms have yet to take effect. In addition, we use the total amount of government subsidies to firms. Research and development subsidies may be related to firm's performance and transformation and upgrading, but the data in this subsidy list are not listed separately. The research can be carried out in future after research and development subsidies are listed separately.

As for the other control variables, cash flows and the ratio of cash paid for assets to the total assets had a significantly positive effect while the assets liabilities ratio had negative impact on the performance of firms. The coefficients of these three variables indicated that sufficient capital and low asset-liability ratio were the necessary conditions to ensure the smooth operation and improve the performance of firms.

In addition, larger scale was conducive to improving the performance of firms. This indicated that the bigger the firm was, the better its performance would be, and whether SOE was not significant. The energy or emission intensive firms were in mature traditional infrastructure 
industries, which still shouldered the national economy and people's livelihood at the current stage of Development in China, and their market size was usually large.

\subsection{The dynamic effect of Green Credit on the performance of energy or emission intensive}

\section{firms}

In order to analyze the annual effect after the implementation of the Green Credit, we referred to Ling et al. (2020). Then, four models, All Sample Without Control Variables DID, All Sample With Control Variables DID, All Sample Without Control Variables DID_PSM and All Sample With Control Variables DID_PSM, were used for demonstration.

Table 6 The dynamic effect of Green Credit on energy or emission intensive firms (Dependent variable: ROA)

In Table 6, the Coefficient of DID under the four methods was negative before 2017 and positive after 2017. Through the longitudinal comparison, the coefficient showed an overall downward trend from 2012 to 2015 , reached the lowest level in 2015, and then picked up gradually. The trend results were shown in Figure 2. It can also be seen that Green Credit had an inhibiting effect on the performance of energy or emission intensive firms in the early stage, but played a promoting role in the long run.

Some detailed results: (1) in Table 6, with the passage of time, although the coefficient of overall a downward trend before 2015, the four model coefficients were not significant in 2012 
and the coefficients were all significant in 2013 in 10\% significance level, which suggested that, in the first year after the implementation of the policy, the inhibiting effect of Green Credit on the performance of energy or emission intensive firms was not obvious and the inhibiting effect began to increase gradually after the second year; (2) in 2017, all the coefficients under the four models were positive, but only statistically significant under the All Sample With Control Variables model, and then all the four models were significantly positive in 2018. Therefore, it can be inferred that Green Credit had a promoting effect on the performance of energy or emission intensive firms from 2017, which was not obvious at the beginning, and the promoting effect was further strengthened in 2018; (3) the coefficients in the four models were all positive but not significant in 2019, which were all slightly lower than that in 2018.

The above results of the dynamic effects were similar to the results in 3.2 section that the coefficient in 2012-2015 was significantly negative and the coefficient in 2016-2019 was positive, which further verified the robustness of the results. Therefore, it can be concluded that Green Credit had an inhibiting effect on the performance of energy or emission intensive firms in the first three years, and the inhibiting effect was gradually strengthened. After 2015, the inhibiting effect weakened and gradually changed into a positive promoting effect. It can be inferred that in the short term, as time goes by, Green Credit had been more strictly and comprehensively implemented, so the inhibiting effect of the policy on firm performance had been strengthened. In the long term, due to Green Credit, energy or emission intensive firms actively improved the environmental governance mechanism, changed the development mode of management and other measures to achieve green loans and improve the firm, and thus the inhibiting effect of Green 
Credit on energy or emission intensive firms' performance gradually weakened and finally promoted their performance.

The above is our analysis based on the empirical results. In section 4, we discuss and analyze the actual development of the energy or emission intensive industries, especially whether any changes have taken place in these industries in 2015.

Figure. 4. The dynamic effect of Green Credit on energy or emission intensive firms

\section{Discussion}

Due to the significant role of external financing, Green Credit can "adjust the structure and change the mode" of China's economy by restricting capital allocation of energy or emission intensive firms and guiding resources away from high-polluting and backward production capacity (He, Zhang, et al., 2019). According to the 2018 Incremental statistics report on the total social financing published by the People's Bank of China, RMB loans to the real economy accounted for 81.4 percent of the total in the same period. As can be seen from Figure 1, since 2015, the performance of energy or emission intensive firms has started to recover, which is consistent with the timeline that energy or emission intensive firms have changed into green firms and the names of energy or emission intensive should be justified stated by an official of the Ministry of Industry and Information Technology. In 2015, energy or emission intensive firms' situation of loan restrictions began to change. At a press conference on the development of the 
industrial communication industry in the first half of 2015, an official of the Ministry of Industry and Information Technology pointed out that in the past, industries such as steel, cement and electrolytic aluminum were high energy-intensive and polluting, but now these industries have turned into energy conservation and environmental protection industries and become superior production capacity (the State Council Information Office, 2015). The vice president of the China Iron and Steel Association, for example, said that "the production process of steel is becoming greener, and the improvement of the quality of steel products is also promoting energy conservation and environmental protection (the State Council Information Office, 2015) ."Our analysis confirmed that Green Credit promoted the upgrading and transformation of energy or emission intensive firms to a certain extent.

The aim of restricting loans to energy or emission intensive firms by Green Credit is not just to shut down a large number of them, as this could lead to serious setbacks to industrial development, mass unemployment and social stability. Green Credit used credit resources to regulate capital flow and imposes punitive interest rates on energy or emission intensive firms in order to accelerate the structural upgrading of polluting industries and ultimately promote the sustainable development and green transformation of industries (He, Zhang, et al., 2019). In the context of the development of Green Credit, the goal of restricting energy or emission intensive firms is to change the traditional production mode of "pollution first, treatment afterwards" (F. Hao et al., 2020). By establishing and improving a legal system of Green Credit, deepening the stakeholders' understanding of Green Credit and adjusting measures to local conditions, Green Credit could effectively promote the upgrading of industrial structure (Y. Hu et al., 2020). For the real estate firms not covered in our paper, there was also one paper showing that the 
transformation of green production of real estate firms was effective because of Green Credit. Z. Yang \& Fang ( 2020) took China's real estate industry as an energy or emission intensive industry, and analyzed its green production efficiency and its dynamic changes. The results indicated that from 2015 to 2018, most real estate firms increased their efforts to improve production technologies and reduce energy consumption during this period, so their green total factor productivity index was greater than 1 and the green productivity of Chinese real estate firms has improved very well.

The development of Green Credit will help change a country's extensive industrial pattern of energy or emission intensive and guide traditional industries to realize energy revolution (F. Hao et al., 2020). Green Credit is not only an effective means for banks and other financial institutions to carry out their social responsibilities, but also the general trend of global financial development. The government and banks can guide the flow of social capital, encourage firms to strengthen energy conservation and emission reduction and develop new energy, so as to change the direction of economic and social development (C. C. Yang et al., 2019).

All the above discussions indicate that, with the development of Green credit, the progress of production technology innovation in energy or emission intensive industries reduced pollution and carbon emissions by 2015, and the performance of those firms gradually improved, which was in line with the conclusion of Section 3, that is, in the long run, Green credit promotes firm's performance. On the other hand, our results showed that financing constraints had a negative effect on the performance of energy or emission intensive firms at the beginning and restricted the development of these firms. This is the same as the research conclusion of some scholars mentioned in the literature review that Green credit has a restrictive effect on those firms. Thus, it 
may hinder the governance of environmental pollution control. Dongyang Zhang, Du, Zhuge, et al. (2019) found a significant negative correlation between financial constraints and firms' input in reducing emissions, and financial constraints tended to reduce firms' investment in R\&D, affecting the effect of environmental improvement.

\section{Conclusions and Proposals}

The rise of Green Credit marks the beginning of a war on emission reduction and energy conservation in China, aimed at realizing the sustainable development of ecological and economic coordination. The role of energy or emission intensive firms is faced with the contradictory demands of promoting economic development and environmental improvement and protection, and appropriate policy interventions are needed to balance the two demands. China's "green credit" policy, implemented in 2012 to restrict loans to energy or emission intensive firms, provides a case study of the impact of such policy interventions.

Using the data of all A-share listed companies in Shanghai and Shenzhen stock exchanges, our paper empirically analyzes the actual impact of Green Credit on bank loans and performance of energy or emission intensive firms. We select "2012 2019", "2012 2015" and "2016 2019" as the implementation period of Green Credit, respectively, and build DID and PSM-DID models to investigate the lasting change of the impact of Green Credit on the performance of energy or emission intensive firms, and use the dynamic test method to analyze the annual effect on the performance of these firms after the implementation of Green Credit. The results of the two methods are consistent, which verifies the robustness of our results.

Our findings and conclusions are as follows: 
First of all, the Green Credit Guidelines issued in 2012 have played a more restrictive role in effectively preventing the risks that could be encountered in the implementation of green credit to energy or emission intensive firms. The results of DID and PSM-DID models showed that Green Credit had a significant negative impact on the performance of these firms in 2012-2015.

Secondly, through dynamic effect analysis, we found that the coefficient from 2012 to 2015 gradually decreased, and the coefficient from 2016 to 2018 gradually increased, and the coefficient changed from negative to positive after 2017. This result indicated that the Green Credit had an inhibiting effect on the performance of energy or emission intensive firms in the first three years, and this inhibiting effect was gradually strengthened. After 2015, the inhibiting effect was weakened and gradually turned into a positive promoting effect.

Thirdly, through analysis and discussion, the performance's change of energy or emission intensive firms around 2015 showed that Green Credit promoted the green transformation and upgrading of energy or emission intensive firms.

Last but not least, loans were helpful to the performance of energy or emission intensive firms to some extent. But government subsidies were not significant. In addition, large size of firms performed better, regardless of whether they were SOE or not.

Based on the above conclusions, this paper proposes some countermeasures.

Green Credit policy should not discriminate energy or emission intensive, but instead based on environmental performance. Then, energy or emission intensive firms have an incentive to pursue the cleaner production because their investment will be rewarded with favorable loans and, ultimately, better business performance (Sun et al., 2019). If the financial constraints of energy or 
emission intensive firms were reduced, these firms could have the funds to increase investment in pollution treatment technology and reduce their energy consumption and pollution, which may improve the environmental performance of these firms and have a positive impact on balancing the development of these firms and solving environmental problems (Y. Hao et al., 2019). At the same time, in order to promote the further development of energy or emission intensive firms, energy conservation and energy efficiency will be an important source of new driving forces for their green development. In addition, ultra-high energy efficiency equipment products and lowenergy buildings have broad market space and application prospects in China, and can continuously form new drivers of green development.

In view of the past one-size-fits-all evaluation of Green Credit, it is suggested that the government, banks and other institutions should inspect the improvement results of firms in real time, so as to dynamically assess the implementation results of Green Credit. The government could establish environmental auditing, environmental risk assessment organizations and other regulatory agencies. These institutions can conduct regular review and objective and reasonable evaluation of the environmental risks of firms from an independent perspective, and provide more effective information for the credit examiners, which is conducive to the prevention and effective control of credit risks of firms by banks. Banks can use big data technology and cooperate with third-party payment platforms to increase funding support for energy or emission intensive firms to develop environmental protection projects under the condition that risks are controllable, so as to further promote the transformation of these firms to "green firms". According to the characteristics of firms with different environmental pollution control needs, banks can develop 
and innovate different green financial products other than Green credit to meet the financing needs of different firms, and expand the financing channels of qualified environmental protection firms.

This paper studied the impact of government subsidies on firm performance. Environmental subsidies in firms are not separated separately due to classification reasons. When future data allow, environmental subsidies can be used to replace government subsidies for analysis. Since corporate environmental disclosure is not mandatory at present and there is a lack of authoritative data on the environment, this paper does not study environmental benefits, which will be a research direction of this paper in the future.

\section{References:}

Ashenfelter, O., \& Card, D. (2006). Using the Longitudinal Structure of Earnings to Estimate the Effect of Training Programs. The Review of Economics and Statistics. https://doi.org/10.2307/1924810

Catalano, M., Forni, L., \& Pezzolla, E. (2020). Climate-change adaptation: The role of fiscal policy. Resource and Energy Economics, 59, 101111. https://doi.org/10.1016/j.reseneeco.2019.07.005

Chen, N., Huang, H. H., \& Lin, C. H. (2018). Equator principles and bank liquidity. International Review of Economics and Finance, 55(July 2017), 185-202. https://doi.org/10.1016/j.iref.2017.07.020

Contreras, G., Bos, J. W. B., \& Kleimeier, S. (2019). Self-regulation in sustainable finance: The adoption of the Equator Principles. World Development, 122, 306-324. https://doi.org/10.1016/j.worlddev.2019.05.030

Gruber, J., \& Poterba, J. (2006). Tax Incentives and the Decision to Purchase Health Insurance: Evidence from the Self-Employed. The Quarterly Journal of Economics. https://doi.org/10.2307/2118419 
Guo, Q., Zhou, M., Liu, N., \& Wang, Y. (2019). Spatial effects of environmental regulation and green credits on green technology innovation under low-carbon economy background conditions. International Journal of Environmental Research and Public Health, 16(17). https://doi.org/10.3390/ijerph16173027

Hao, F., Xie, Y., \& Liu, X. (2020). The Impact of Green Credit Guidelines on the Technological Innovation of Heavily Polluting Enterprises : A Quasi-Natural Experiment from China. Mathematical Problems in Engineering, 2020.

Hao, Y., \& Yan, J. (2020). The Influence of Green-credit Policy on the Financial Performance and Operating Risk of Enterprises with High Pollution and Energy Consumption Hao. Journal of Environmental Economics, 2, 34-49.

Hao, Y., Ye, B., Gao, M., Wang, Z., Chen, W., Xiao, Z., \& Wu, H. (2019). How does ecology of finance affect financial constraints? Empirical evidence from Chinese listed energy- and pollution-intensive companies. Journal of Cleaner Production, 246, 119061.

https://doi.org/10.1016/j.jclepro.2019.119061

Harper Ho, V. E. (2018). Sustainable Finance \& China’s Green Credit Reforms: A Test Case for Bank Monitoring of Environmental Risk. SSRN Electronic Journal, 51. https://doi.org/10.2139/ssrn.3124304

He, L., Wu, C., Yang, X., \& Liu, J. (2019). Corporate social responsibility, green credit, and corporate performance: an empirical analysis based on the mining, power, and steel industries of China. Natural Hazards, 95(1-2), 73-89. https://doi.org/10.1007/s11069-018-3440-7 
He, L., Zhang, L., Zhong, Z., Wang, D., \& Wang, F. (2019). Green credit, renewable energy investment and green economy development: Empirical analysis based on 150 listed companies of China. Journal of Cleaner Production, 208, 363-372. https://doi.org/10.1016/j.jclepro.2018.10.119

Heckman, J. J., Ichimura, H., \& Todd, P. E. (1997). Matching as an econometric evaluation estimator: Evidence from evaluating a job training programme. The Review of Economic Studies, 64(221), 605654.

Hu, G., Wang, X., \& Wang, Y. (2021). Can the green credit policy stimulate green innovation in heavily polluting enterprises? Evidence from a quasi-natural experiment in China. Energy Economics, 98, 105134. https://doi.org/10.1016/j.eneco.2021.105134

Hu, Y., Jiang, H., \& Zhong, Z. (2020). Impact of green credit on industrial structure in China: theoretical mechanism and empirical analysis. Environmental Science and Pollution Research, 27(10), 1050610519. https://doi.org/10.1007/s11356-020-07717-4

Junli, L. (2013). Enterprises' Green Credit Assessment-From the Perspective of Financial Institutions' Green Credit. Contemporary Logistics, 10, 91-99. https://doi.org/10.5503/J.CL.2013.10.017

Lechner, M. (2010). Methods, The Estimation of Causal Effects by Difference-in-Difference. Foundations and Trends in Econometrics. https://doi.org/10.1561/0800000014

Lee, J. W. (2020). Green finance and sustainable development goals: The case of China. Journal of Asian Finance, Economics and Business, 7(7), 577-586. https://doi.org/10.13106/jafeb.2020.vol7.no7.577 
Ling, S., Han, G., An, D., Hunter, W. C., \& Li, H. (2020). The impact of green credit policy on technological innovation of firms in pollution-intensive industries: Evidence from China. Sustainability (Switzerland), 12(11), 1-16. https://doi.org/10.3390/su12114493

Liu, J. Y., Xia, Y., Fan, Y., Lin, S. M., \& Wu, J. (2015). Assessment of a green credit policy aimed at energy-intensive industries in China based on a financial CGE model. Journal of Cleaner Production, 163, 293-302. https://doi.org/10.1016/j.jclepro.2015.10.111

Liu, J., Zhao, M., \& Wang, Y. (2020). Impacts of government subsidies and environmental regulations on green process innovation: A nonlinear approach. Technology in Society, 63(September), 101417. https://doi.org/10.1016/j.techsoc.2020.101417

Liu, X., Wang, E., \& Cai, D. (2019). Green credit policy, property rights and debt financing: Quasi-natural experimental evidence from China. Finance Research Letters, 29(March), 129-135.

https://doi.org/10.1016/j.frl.2019.03.014

Nabeeh, N. A., Abdel-Basset, M., \& Soliman, G. (2021). A model for evaluating green credit rating and its impact on sustainability performance. Journal of Cleaner Production, 280, 124299. https://doi.org/10.1016/j.jclepro.2020.124299

Nandy, M., \& Lodh, S. (2012). Do banks value the eco-friendliness of firms in their corporate lending decision? Some empirical evidence. International Review of Financial Analysis, 25, 83-93. https://doi.org/10.1016/j.irfa.2012.06.008

Sadorsky, P. (2010). The impact of financial development on energy consumption in emerging economies. Energy Policy, 38(5), 2528-2535. https://doi.org/10.1016/j.enpol.2009.12.048 
Scholtens, B., \& Dam, L. (2007). Banking on the Equator. Are Banks that Adopted the Equator Principles Different from Non-Adopters? World Development, 35(8), 1307-1328. https://doi.org/10.1016/j.worlddev.2006.10.013

Song, M., Xie, Q., \& Shen, Z. (2021). Impact of green credit on high-efficiency utilization of energy in China considering environmental constraints. Energy Policy, 153(February), 112267. https://doi.org/10.1016/j.enpol.2021.112267

Stephens, C., \& Skinner, C. (2013). Banks for a better planet? The challenge of sustainable social and environmental development and the emerging response of the banking sector. Environmental Development, 5(1), 175-179. https://doi.org/10.1016/j.envdev.2012.11.011

Sun, J., Wang, F., Yin, H., \& Zhang, B. (2019). Money Talks: The Environmental Impact of China’s Green Credit Policy. Journal of Policy Analysis and Management, 38(3), 653-680. https://doi.org/10.1002/pam.22137

the State Council Information Office. (2015). A press conference on the development of the industrial communication industry in the first half of 2015. China.Com. http://www.china.com.cn/zhibo/201507/22/content_36100090.htm?show=t

Wang Kangshi, Sun Xuran, W. F. (2019). Green Finance, Financing Constrains and the Investment of Polluting Enterprise. CONTEMPORARY ECONOMIC MANAGEMENT, 41(12).

Wang, Yang, \& Zhang, Y. (2020). Do state subsidies increase corporate environmental spending? International Review of Financial Analysis, 72(August), 101592. https://doi.org/10.1016/j.irfa.2020.101592 
Wang, Yanli, Lei, X., Long, R., \& Zhao, J. (2020). Green Credit, Financial Constraint, and Capital Investment: Evidence from China's Energy-intensive Enterprises. Environmental Management. https://doi.org/10.1007/s00267-020-01346-w

Wen, H., Lee, C. C., \& Zhou, F. (2021). Green credit policy, credit allocation efficiency and upgrade of energy-intensive enterprises. Energy Economics, 94, 105099. https://doi.org/10.1016/j.eneco.2021.105099

Xing, C., Zhang, Y., \& Wang, Y. (2020). Do Banks Value Green Management in China? The Perspective of the Green Credit Policy. Finance Research Letters, 35(May), 101601. https://doi.org/10.1016/j.frl.2020.101601

Xiong, Y., \& Yang, X. (2016). Government subsidies for the Chinese photovoltaic industry. Energy Policy, 99(October), 111-119. https://doi.org/10.1016/j.enpol.2016.09.013

Xu, J., \& Nickel, S. (2017). Proceedings of the tenth international conference on management science and engineering management. In Advances in Intelligent Systems and Computing (Vol. 502). https://doi.org/10.1007/978-981-10-1837-4_139

Xu, S. (2020). International comparison of green credit and its enlightenment to China. Green Finance, 2(1), 75-99. https://doi.org/10.3934/gf.2020005

Xu, X., \& Li, J. (2020). Asymmetric impacts of the policy and development of green credit on the debt financing cost and maturity of different types of enterprises in China. Journal of Cleaner Production, 264, 121574. https://doi.org/10.1016/j.jclepro.2020.121574 
Yang, C. C., Ou, S. L., \& Hsu, L. C. (2019). A hybrid multi-criteria decision-making model for evaluating companies' green credit rating. Sustainability (Switzerland), 11(6). https://doi.org/10.3390/su11061506

Yang, Z., \& Fang, H. (2020). Research on green productivity of chinese real estate companies-based on SBM-DEA and TOBIT models. Sustainability (Switzerland), 12(8). https://doi.org/10.3390/SU12083122

Yu, F. S., \& Chi, H. W. (2010). Green credit loan as environmental policy. Environmental Economics, 1(1).

Zhang, B., Yang, Y., \& Bi, J. (2011). Tracking the implementation of green credit policy in China: Topdown perspective and bottom-up reform. Journal of Environmental Management, 92(4), 1321-1327. https://doi.org/10.1016/j.jenvman.2010.12.019

Zhang, Dayong, Zhang, Z., \& Managi, S. (2019). A bibliometric analysis on green finance: Current status, development, and future directions. Finance Research Letters, 29(January), 425-430. https://doi.org/10.1016/j.frl.2019.02.003

Zhang, Dongyang, Du, P., \& Chen, Y. (2019). Can designed financial systems drive out highly polluting firms? An evaluation of an experimental economic policy. Finance Research Letters, 31(July), 218224. https://doi.org/10.1016/j.frl.2019.08.032

Zhang, Dongyang, Du, W., Zhuge, L., Tong, Z., \& Freeman, R. B. (2019). Do financial constraints curb firms' efforts to control pollution? Evidence from Chinese manufacturing firms. Journal of Cleaner Production, 215, 1052-1058. https://doi.org/10.1016/j.jclepro.2019.01.112 
Zhang, H., Li, L., Zhou, D., \& Zhou, P. (2014). Political connections , government subsidies and fi rm fi nancial performance : Evidence from renewable energy manufacturing in. 63, 330-336. https://doi.org/10.1016/j.renene.2013.09.029

Zhang, R., Ma, W., \& Liu, J. (2020). Impact of government subsidy on agricultural production and pollution: A game-theoretic approach. Journal of Cleaner Production, xxxx, 124806. https://doi.org/10.1016/j.jclepro.2020.124806

Zhang, Y., Xing, C., \& Wang, Y. (2020). Does green innovation mitigate financing constraints? Evidence from China’s private enterprises. Journal of Cleaner Production, 264, 121698.

https://doi.org/10.1016/j.jclepro.2020.121698 